\title{
Electrolyte Disturbances in Cerebrovascular Stroke
}

\author{
ASMAA Z.M. KASEM, M.Sc.; WAFAA M.A. FARGHALY, M.D. and AMAL M.A. TOHAMY, M.D. \\ The Department of Neuropsychiatry, Faculty of Medicine, Assiut University, Assiut, Egypt
}

\begin{abstract}
Background: Stroke is a major public health problem. It is one of the leading causes of chronic disability and the second leading cause of death. Electrolyte disturbances have negative influences on the outcome of stroke.

Aim of Study: The aim of this study was to find out the relative frequency of electrolyte disturbances among acute stroke patients; and their relationship with severity and outcome of acute stroke. This study was a descriptive proscriptive one.

Material and Methods: Samples consisted of 331 patients with first ever acute CVS $(<48)$ recruited from emergency department, ICU, stroke unite or inward Neurology Department of Assiut University Hospital. Patients with well-known organ failure were excluded. Patients were evaluated clinically on admission and discharge (within one week) by NIHSS together with estimation of serum electrolyte levels.
\end{abstract}

Results: The result shows that the most common disturbances was potassium disturbances (25.7\%), followed by Sodium disturbances $(22.0 \%)$, while calcium disturbances and magnesium disturbances recorded in nearly a similar rate (15.1\% \# 15.4\%) from all studied samples. Patients presented with severe CVS (NIHSS >15) had the highest rates of dysnatremia, dyskalemia, dysmagnesemia with significance association between dysnatremia and severity of stroke $(p=$ 0.006). Survivals of acute CVS patients with dysnatremia and dyskalemia showed clinical deterioration. This deterioration was significant among cases with hyponatremia, hypernatremia and hypokalemia who were not amenable for correction of their electrolyte disturbances. Among cases who died of acute CVS dysnatremia was the most commonly encountered electrolyte disturbances $(40.0 \%)$.

Conclusion: The incidence of electrolyte disorders in acute stroke patients was high, and severe CVS cases had the highest rates of dysnatremia, dyskalemia, and dysmagnesemia. Dysnatremia had significant association with stroke severity. Dysnatremia and dyskalemia affect prognosis of stroke negatively.

Key Words: Electrolyte disturbances - Sodium - Potassium - Calcium - Magnesium - Severity - Stroke Outcome - Acute stroke.

Correspondence to: Dr. Asmaa Z. Mohamed, E-Mail: asmaazidan82@hotmail.com

\section{Introduction}

STROKE is the second leading cause of death; it ranked after heart disease and before cancer, [1] and is the most disabling of all neurological diseases. The total lifetime prevalence of stroke among population aged 20 years and more in Upper Egypt (desert area) was 8.5/1,000, [2] . Nearly one third of stroke patient die within 3 weeks and $48 \%$ die within one year. High mortality in stroke is due to some complications like cerebral edema, brainstem herniation, infection, associated heart disease, metabolic disorders and electrolytes disturbances, [3]

Electrolytes are important because they are what cells use to maintain voltages across their cell membranes and to carry electrical impulses. $\mathrm{Na}, \mathrm{K}, \mathrm{Ca}$ and $\mathrm{Mg}$ are major body electrolytes; [4] Sodium influences osmotic equilibrium, blood volume, blood pressure and plays a major role in acid-base balance. The concentration of plasma sodium depends on its dilution with water, [5] Potassium is a basic need for the brain and essential for neuronal cell health, function, and cerebral circulation, [6] . Calcium (Ca2+) ions play a physiological role in the multiple pathomechanisms of cerebral ischemia. Cell calcium metabolism during and immediately after a transient period of ischemia influences the cascade of events that leads to subsequent neuronal injury, [7]. Magnesium is one of trace metals which have important influences on brain development and function, [8]. Magnesium is an important electrolyte and may have properties which protect the brain by acting as a glutamate receptor antagonist and calcium channel blocker, [9].

\section{Aim of study:}

We tried to find out the relative frequency of electrolyte disturbances among acute stroke patients; and their relationship with severity and short-term outcome. 


\section{Subjects and Methods}

This was a prospective descriptive hospitalbased study conducted in Assuit University Hospital. The study extended along 6 months from the 1 st of June 2015 to the end of November 2015. During this period all patients with 1 st ever stroke attending the Emergency Department, Stroke Unite, ICU or Neurology Inward Department during their first 48 hours of stroke occurrence $(n=331)$ were included in the study.

Inclusion criteria were: First ever stroke patients (ischemic and hemorrhagic stroke) at first 48 hours of the CVS onset, patients with any age groups, both sexes are included in this study.

Exclusion criteria: Patients on renal dialysis, other neurological diseases other than stroke, recurrent stroke, organ failures (liver cell failure, cardiac failure, renal failure). Diagnosis of stroke was based on history of disease, physical and neurological examination and confirmed by neuroimaging study. All patients were subjected to: Demographic data collection and detailed clinical history with special emphasis on time elapsed since the onset of stroke, comorbid conditions, and risk factors of stroke: HTN, DM, renal troubles, history of current antihypertensive or antidiabetics treatment whether oral hypoglycemic or insulin therapy. Estimation of stroke severity was assessed on admission and on discharge using NIHSS as follow: Mild stroke with NIHSS <4, moderate stroke if NIHSS ranges from $4-15$, while score $>15$ was considered as sever stroke. Electrolytes analyzed in this study were sodium, potassium, ionized calcium, and ionized magnesium. Normal range of studied electrolyte were as follow: Sodium level in a range of $(135-150 \mathrm{Meq} / \mathrm{L})$, Potassium level (3.5-5 Meq/L), Calcium level (1.16-1.36Meq/L), and Magnesium level (1.8-2.4Meq/L).

In Statistical analysis categorical variables were described by number and percent (n, \%), where continuous variables described by mean and standard deviation (mean, SD). Chi-square test used to compare between categorical variables where compare between continuous variables by $t$-test Plots. A two-tailed $p<0.05$ was considered statistically significant. All analyses were performed with the SPSS 20.0 software. Relations and differences were considered significant according to the level of significance as follow: $p<0.05$ : Insignificant, $p>0.005$ : Significant, $p>0.01$ : Highly significant, and $p>0.001$ : Very highly significant. The study was approved by Local Ethics Committee in Faculty of Medicine Assuit University. The confidentiality of patient's data was maintained during all steps of the study.

\section{Results}

331 patients were recorded with acute CVS ( $>48 \mathrm{hs}$ ) along period of study. Their mean age was $56.2 \pm 11.9$ with the highest rate of age specific incidence CVS (41.9\%) between 50-60 years of age $56.5 \%$ were males. The majority of patients had arterial ischemic stroke (63.1\%), and the most affected artery was MCA (75.8\%), most of the patients $(66.8 \%)$ had severe stroke (NIHSS >15), and mortality rate of the studied sample was $(13.6 \%)$.

Based on electrolyte status, potassium disturbances was the most encountered in acute CVS patients $(25.7 \%)$, followed by sodium disturbances $(22.0 \%)$ especially hyponatremia and hypokalemia $(17.8 \%)$ for each, (Table 1).

Table (1): Rates of electrolyte levels along the 1 st week of CVS.

\begin{tabular}{lll}
\hline & \multicolumn{2}{c}{1 st day $(\mathrm{n}=331)$} \\
\cline { 2 - 3 } & No. & $\%$ \\
\hline Normal Na & 258 & 77.9 \\
Abnormal & 73 & 22.0 \\
Low & 59 & 17.8 \\
High & 14 & 4.2 \\
Normal K & 246 & 74.3 \\
Abnormal & 85 & 25.7 \\
Low & 59 & 17.8 \\
High & 26 & 7.9 \\
Normal Ca & 281 & 84.9 \\
Abnormal & 50 & 15.1 \\
Low & 46 & 13.9 \\
High & 4 & 1.2 \\
Normal Mg & 280 & 84.6 \\
Abnormal & 51 & 15.4 \\
Low & 49 & 14.8 \\
High & 2 & 0.6
\end{tabular}

Patients presented with severe CVS (NIHSS $>15$ ) had the highest rates of dysnatremia, dyskalemia, and dysmagnesemia, and this was particularly significant for dysnatremia ( $p=0.006$ ), (Table 2).

Dysnatremia was recorded in a similar rate (22\%) among patients with ischemic and hemorrhagic stroke, while dyskalemia, dyscalcemia, and dysmagnesemia were recorded with slightly higher rates among hemorrhagic stroke patients; but the difference was statically insignificant, (Table 3 ).

Brain stem stroke was associated with the highest rates of all electrolytes disturbances, (Table 4). 
Table (2): Relationship between stroke severity on presentation and rate of electrolyte disturbances among acute stroke patients.

\begin{tabular}{|c|c|c|c|c|c|c|c|c|c|c|c|c|c|}
\hline & \multicolumn{6}{|c|}{$\mathrm{NIH}$} & \multirow{4}{*}{$\begin{array}{c}p- \\
\text { value }\end{array}$} & & \multicolumn{4}{|c|}{ Type of stroke } & \multirow{3}{*}{$\begin{array}{c}p- \\
\text { value }\end{array}$} \\
\hline & \multirow{2}{*}{\multicolumn{2}{|c|}{$\begin{array}{c}\text { Mild } \\
<4 \\
(n=4)\end{array}$}} & \multirow{2}{*}{\multicolumn{2}{|c|}{$\begin{array}{c}\text { Moderate } \\
4-15 \\
(n=106)\end{array}$}} & \multirow{2}{*}{\multicolumn{2}{|c|}{$\begin{array}{c}\text { Severe } \\
>15 \\
(n=221)\end{array}$}} & & & \multicolumn{2}{|c|}{$\begin{array}{c}\text { Ischemic } \\
(\mathrm{n}=218)\end{array}$} & \multicolumn{2}{|c|}{$\begin{array}{l}\text { Hemorrhagic } \\
\qquad(\mathrm{n}=113)\end{array}$} & \\
\hline & & & & & & & & & No. & $\%$ & No. & $\%$ & \\
\hline & No. & $\%$ & No. & $\%$ & No. & $\%$ & & \multirow{2}{*}{$\begin{array}{l}\text { Normal } \\
\text { Dysnatremia }\end{array}$} & 170 & 78.0 & 88 & 77.9 & 0.982 \\
\hline \multirow{2}{*}{$\begin{array}{l}\text { Normal Na }(\mathrm{n}=258) \\
\text { Dysnatremia }\end{array}$} & 4 & 100 & 93 & 87.7 & 161 & 72.9 & $0.006^{*}$ & & 48 & 22.0 & 25 & 22.1 & 0.982 \\
\hline & 0 & 0.0 & 13 & 12.3 & 60 & 27.1 & $0.006^{*}$ & Low & 37 & 17.0 & 22 & 19.5 & 0.574 \\
\hline Low $(n=59)$ & 0 & 0.0 & 10 & 9.4 & 49 & 22.2 & $0.012 *$ & \multirow[t]{2}{*}{ High } & \multirow[t]{2}{*}{11} & \multirow[t]{2}{*}{5.0} & \multirow[t]{2}{*}{3} & \multirow[t]{2}{*}{2.7} & \multirow[t]{2}{*}{0.461} \\
\hline High $(n=14)$ & 0 & 0.0 & 3 & 2.8 & 11 & 4.9 & 0.608 & & & & & & \\
\hline & & 100 & 85 & & & & & \multirow{2}{*}{$\begin{array}{l}\text { Normal } \\
\text { Dyskalemia }\end{array}$} & 166 & 76.1 & 80 & 70.8 & 0.291 \\
\hline $\begin{array}{l}\text { Dyskalemia } \\
\text { Dysmal }(n=240)\end{array}$ & $\begin{array}{l}4 \\
0\end{array}$ & $\begin{array}{l}100 \\
0.0\end{array}$ & $\begin{array}{l}85 \\
21\end{array}$ & $\begin{array}{l}80.2 \\
19.8\end{array}$ & $\begin{array}{l}15 / \\
64\end{array}$ & $\begin{array}{l}71.0 \\
28.9\end{array}$ & $\begin{array}{l}0.103 \\
0.103\end{array}$ & & 52 & 23.9 & 33 & 29.2 & 0.291 \\
\hline Low $(n=59)$ & 0 & 0.0 & 15 & 14.2 & 44 & 19.9 & 0.286 & Low & 33 & 15.1 & 26 & 23.0 & 0.076 \\
\hline $\operatorname{High}(n=26)$ & 0 & 0.0 & 6 & 5.7 & 20 & 9.0 & 0.477 & High & 19 & 8.7 & 7 & 6.2 & 0.419 \\
\hline Normal Ca (n=281) & 3 & 75 & 89 & 83.9 & 189 & 85.5 & 0.801 & Normal & 187 & 85.8 & 94 & 83.2 & 0.532 \\
\hline Dyscalcemia & 1 & 25 & 17 & 16.03 & 32 & 14.5 & 0.801 & Dyscalcemia & 31 & 14.2 & 19 & 16.8 & 0.532 \\
\hline Low $(n=46)$ & 1 & 25 & 17 & 16.03 & 28 & 12.7 & 0.578 & & 29 & 13.3 & 17 & 15.0 & 0.664 \\
\hline High $(n=4)$ & 0 & 0.0 & 0 & 0 & 4 & 1.8 & 0.365 & Low & 29 & 15.3 & 17 & 10.0 & \\
\hline Normal Mg $(n=280)$ & 4 & 100 & 96 & 90.6 & 180 & 81.4 & 0.070 & High & 2 & 0.9 & 2 & 1.8 & 0.887 \\
\hline Dysmagnesemia & 0 & 0.0 & 10 & 9.4 & 41 & 18.6 & 0.070 & Normal & 187 & 85.8 & 93 & 82.3 & 0.406 \\
\hline Low $(n=49)$ & 0 & 0.0 & 10 & 9.4 & 39 & 17.6 & 0.104 & Dysmagnesemia & 31 & 14.2 & 20 & 17.7 & 0.406 \\
\hline High $(n=2)$ & 0 & 0.0 & 0 & 0 & 2 & 0.9 & 0.606 & & & & & & \\
\hline $\begin{array}{l}* \text { Statistical significa } \\
\text { All data are presente }\end{array}$ & ner & t & 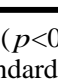 & eviat & & & & $\begin{array}{l}\text { Low } \\
\text { High }\end{array}$ & $\begin{array}{l}30 \\
1\end{array}$ & $\begin{array}{l}15.8 \\
0.5\end{array}$ & 19 & $\begin{array}{l}10.8 \\
0.9\end{array}$ & 0.635 \\
\hline
\end{tabular}

Table (4): Relationship between site of stroke and rate of electrolyte disturbances among stroke patients.

\begin{tabular}{|c|c|c|c|c|c|c|c|c|c|c|c|c|c|c|}
\hline & \multicolumn{2}{|c|}{$\begin{array}{c}\text { BG + Capsular } \\
N=66\end{array}$} & \multicolumn{2}{|c|}{$\begin{array}{r}\text { Lobar } \\
\mathrm{N}=183\end{array}$} & \multicolumn{2}{|c|}{$\begin{array}{c}\mathrm{IVH} \\
\mathrm{N}=28\end{array}$} & \multicolumn{2}{|c|}{$\begin{array}{l}\mathrm{SAH} \\
\mathrm{N}=14\end{array}$} & \multicolumn{2}{|c|}{$\begin{array}{l}\text { Cerebellar } \\
\quad \mathrm{N}=12\end{array}$} & \multicolumn{2}{|c|}{$\begin{array}{c}\text { Thalamic } \\
\mathrm{N}=44\end{array}$} & \multicolumn{2}{|c|}{$\begin{array}{c}\text { Brain stem } \\
\mathrm{N}=22\end{array}$} \\
\hline & No. & $\%$ & No. & $\%$ & No. & $\%$ & No. & $\%$ & No. & $\%$ & No. & $\%$ & No. & $\%$ \\
\hline \multicolumn{15}{|l|}{$N a:$} \\
\hline Normal & 55 & 83.3 & 145 & 79.3 & 18 & 64.3 & 6 & 42.9 & 12 & 100.0 & 34 & 77.3 & 4 & 18.2 \\
\hline Abnormal & 12 & 18.2 & 37 & 20.2 & 10 & 35.7 & 8 & 57.1 & 0 & 0.0 & 10 & 22.8 & 18 & 81.8 \\
\hline Low & 11 & 16.7 & 29 & 15.8 & 8 & 28.6 & 6 & 42.9 & 0 & 0.0 & 9 & 20.5 & 15 & 68.2 \\
\hline High & 1 & 1.5 & 8 & 4.4 & 2 & 7.1 & 2 & 14.3 & 0 & 0.0 & 1 & 2.3 & 3 & 13.6 \\
\hline Normal & 46 & 69.7 & 136 & 74.3 & 19 & 67.9 & 11 & 78.6 & 8 & 66.7 & 37 & 84.1 & 10 & 45.5 \\
\hline Dyskalemia & 21 & 31.8 & 46 & 25.2 & 9 & 32.1 & 3 & 21.4 & 4 & 33.3 & 7 & 15.9 & 12 & 54.5 \\
\hline Low & 18 & 27.3 & 27 & 14.8 & 7 & 25.0 & 3 & 21.4 & 3 & 25.0 & 6 & 13.6 & 9 & 40.9 \\
\hline High & 3 & 4.5 & 19 & 10.4 & 2 & 7.1 & 0 & 0.0 & 1 & 8.3 & 1 & 2.3 & 3 & 13.6 \\
\hline Normal & 57 & 86.4 & 159 & 86.9 & 22 & 78.6 & 10 & 71.4 & 10 & 83.3 & 36 & 81.8 & 14 & 63.6 \\
\hline Dyscalcemia & 10 & 15.2 & 23 & 12.6 & 6 & 21.4 & 4 & 28.6 & 2 & 16.7 & 8 & 18.2 & 8 & 36.4 \\
\hline Low & 10 & 15.2 & 21 & 11.5 & 6 & 21.4 & 4 & 28.6 & 2 & 16.7 & 8 & 18.2 & 6 & 27.3 \\
\hline High & 0 & 0.0 & 2 & 1.1 & 0 & 0.0 & 0 & 0.0 & 0 & 0.0 & 0 & 0.0 & 2 & 9.1 \\
\hline Normal & 57 & 86.4 & 155 & 84.7 & 22 & 78.6 & 10 & 71.4 & 9 & 75.0 & 36 & 81.8 & 15 & 68.2 \\
\hline Dysmagnesemia & 10 & 15.2 & 27 & 14.8 & 6 & 21.4 & 4 & 28.6 & 3 & 25.0 & 8 & 18.2 & 7 & 31.8 \\
\hline Low & 10 & 15.2 & 25 & 13.7 & 6 & 21.4 & 4 & 28.6 & 3 & 25.0 & 8 & 18.2 & 7 & 31.8 \\
\hline High & 0 & 0.0 & 2 & 1.1 & 0 & 0.0 & 0 & 0.0 & 0 & 0.0 & 0 & 0.0 & 0 & 0.0 \\
\hline
\end{tabular}


It was found that among survivals of acute CVS, patients with electrolytes disturbances showed clinical deterioration. This was significant among cases with hyponatremia, hypernatremia, and hypokalemia who were not amenable for correction, (Table 5).

Table (5): Short-term outcome of CVS (based on NIHSS) in relation to electrolytes disturbances on presentation.

\begin{tabular}{|c|c|c|c|}
\hline & \multicolumn{2}{|c|}{ NIHSS } & \multirow{2}{*}{$\begin{array}{c}p- \\
\text { value }\end{array}$} \\
\hline & $\begin{array}{c}\text { At admission } \\
\text { Mean } \pm \text { SD }\end{array}$ & $\begin{array}{c}\text { At discharge } \\
\text { Mean } \pm \text { SD }\end{array}$ & \\
\hline Normal $\mathrm{Na}$ & $21.21 \pm 7.99$ & $20.13 \pm 10.24$ & 0.401 \\
\hline Low and improved $\mathrm{Na}$ & $23.83 \pm 8.18$ & $21.81 \pm 10.30$ & 0.975 \\
\hline Low and deteriorated $\mathrm{Na}$ & $23.04 \pm 7.69$ & $26.50 \pm 11.51$ & $0.000 *$ \\
\hline High and improved & $25.44 \pm 7.90$ & $23.74 \pm 10.35$ & 0.690 \\
\hline High and deteriorated & $19.33 \pm 5.96$ & $21.83 \pm 7.19$ & $0.022 *$ \\
\hline Normal K & $21.83 \pm 8.07$ & $20.89 \pm 10.45$ & 0.502 \\
\hline Low and improved $\mathrm{K}$ & $21.79 \pm 7.39$ & $20.15 \pm 9.72$ & 0.554 \\
\hline Low and deteriorated & $21.95 \pm 9.83$ & $24.05 \pm 13.31$ & $0.006^{*}$ \\
\hline High and improved & $23.10 \pm 7.97$ & $22.45 \pm 11.06$ & 0.139 \\
\hline High and deteriorated & $28.67 \pm 3.21$ & $37.00 \pm 8.66$ & 0.120 \\
\hline Normal Ca & $21.78 \pm 7.99$ & $22.96 \pm 10.59$ & 0.134 \\
\hline Low and improved $\mathrm{Ca}$ & $20.98 \pm 9.77$ & $24.17 \pm 13.53$ & $0.012 *$ \\
\hline Low and deteriorated & $24.30 \pm 7.67$ & $25.60 \pm 10.32$ & 0.484 \\
\hline High and improved & $26.75 \pm 3.86$ & $29.00 \pm 5.48$ & 0.328 \\
\hline \multicolumn{4}{|l|}{ High and deteriorated } \\
\hline Normal Mg & $21.15 \pm 8.09$ & $22.18 \pm 10.68$ & 0.104 \\
\hline Low and improved $\mathrm{Mg}$ & $23.58 \pm 7.05$ & $26.18 \pm 10.29$ & $0.003^{*}$ \\
\hline Low and deteriorated & $26.20 \pm 8.63$ & $26.67 \pm 9.72$ & 0.730 \\
\hline High and improved & $26.00 \pm 0.00$ & $27.00 \pm 0.00$ & 0.157 \\
\hline High and deteriorate & & & \\
\hline
\end{tabular}

*: Statistical significant difference $(p<0.05)$.

All data are presented mean \pm standard deviation.

Dysnatremia was the most commonly encountered electrolyte disturbances (40\%) among cases who died within one week of stroke, (Table 6).

Table (6): Rates of electrolyte disturbance among deaths of CVS within the 1 st week of stroke.

\begin{tabular}{lll}
\hline & \multicolumn{2}{c}{ Outcome } \\
& \multicolumn{2}{c}{ Died $(\mathrm{n}=45)$} \\
\cline { 2 - 3 } & No. & $\%$ \\
\hline Normal Na & 27 & 60.0 \\
Abnormal & 18 & 40.0 \\
Low & 15 & 33.3 \\
High & 3 & 6.7 \\
Normal K & 30 & 66.7 \\
Abnormal & 15 & 33.3 \\
Low & 10 & 22.2 \\
High & 5 & 11.1 \\
Normal Ca & 35 & 77.8 \\
Abnormal & 10 & 22.2 \\
Low & 10 & 22.2 \\
High & 0 & 0.0 \\
Normal Mg & 34 & 75.6 \\
Abnormal & 11 & 24.4 \\
Low & 11 & 24.4 \\
High & 0 & 0.0 \\
\hline
\end{tabular}

\section{Discussion}

This study included 331 patients with 1 st ever CVS stroke. Highest rate of age specific CVS $(41.9 \%)$ was between $(>50<60$ years). This rate is higher than that recorded by Hassan et al., [10], in India who found that only $24.3 \%$ of CVS patients aged 51-60 years. Although, in general, the international incidence of stroke is increasing with increasing age, [11,12], this higher incidence $(41.9 \%)$ among young adults $(>50-<60 \mathrm{ys})$ might reflect inadequate 1ry prevention protocol strategy for CVS in our country. In the current study the majority of the patients $65.9 \%$ had Ischemic stroke, and the ratio of Ischemic to $\mathrm{Hg}$ stroke is 1.9:1. Which is similar to the international incidence reported by WHO (2:1) [13].

In the present study, dyskalemia was the most commonly recorded electrolyte disturbance (25.7\%) $(\mathrm{n}=85 / 331)$ among patients presenting with 1 st ever acute stroke, particularly hypokalemia which was encountered in a higher rate among those with hemorrhagic stroke than in ischemic stroke (23.0\% \#15.1\%). On the contrary, dysnatremia was the most commonly encountered electrolyte disturbance in other studies $[10,14]$ which recorded dysnatremia in $47.3 \%$ and $38.6 \%$, while they recorded dyskalemia among $32.7 \%$ and $28.8 \%$ of acute stroke patients respectively.

This lower rate of dysnatremia and dyskalemia recorded in the current study could be attributed to the restrictive inclusion criteria to only those with 1 st ever CVS. There is no doubt that those with 1 st ever CVS had shorter duration and/or less risk factors than those who have recurrent stroke. On the other hand in Manado study in Indonesia, only $8.2 \%$ of acute stroke patients were found to have dysnatremia, $(7.1 \%$ hyponatremia $\& 1.2 \%$ hypernatremia), [15]. This might be related to the small sample size ( $\mathrm{n}=85$ patient), beside the wider normal range of the serum sodium level (135-153), as well as their adopted exclusion criteria, where they exclude patients on diuretics, and patients with renal impairment, even if acute.

As regard electrolyte disturbance in relation to stroke severity according to NIHSS, it was found that patients presenting with severe CVS (NIHSS $>15$ ), had the highest rate of electrolyte disturbances (dysnatremia, dyskalemia, dysmagnesemia). This association between electrolyte disturbances and severe CVS could be explained on bimodal cause and effect relationship. On one hand CVS might be a cause of electrolyte disturbances, for example hyponatremia due either to Syndrome of Inappro- 
priate secretion of ADH or Cerebral Salt Wasting Syndrom, [16,17]. On the other hand, these electrolyte disturbances will contribute to altering sensorial level and consequently to stroke severity. On the contrary, Mieke et al., (2014), [15], among a small sample size $(n=85)$ found no association between severity of stroke and electrolyte disturbances.

In the current study it was found that brain stem stroke was associated with the highest rate of electrolyte disturbances compared to any other site of stroke. Our results are in partial agreement with earlier study carried by Kusuda (1989) and his colleagues, [18], who found that in hemorrhagic stroke, the incidence of hypernatremia was the highest in those with brain stem lesion. On the contrary Guo, [19], reported that patients with thalamic hemorrhage are more likely to have electrolyte disturbances than those with non-thalamic hemorrhage.

Among survival, it was found that patients with electrolyte disturbances showed significant deterioration with significant increase in NIHSS on discharge compared to that on admission particularly those with uncorrected hyponatremia, hypernatremia, hypokalemia, hypocalcemia and hypomagnesemia. In agreement with this current study, Lath et al., [20], Aiyagari et al., [21], and Siddique et al., [22], found that acute hyponatremia in acute stroke affects the outcome of stroke negatively either in the form of clinical deterioration, or death. Similarly, Huang et al., [23], recorded higher mortality rate of hyponatremic CVS patients than normonatremic patients.

However, Rodrigues [24], found that patients with hyponatremia showed significant deterioration with significant increase in NIHSS on discharge compared to that on admission, prolonged hyponatremia might leads to cerebral edema, encephalopathy, tissue damage and seizure which could be a part of extension in avascular injures after acute ischemic syndrome. In this present study it was found that among cases who died within the 1 st week of CVS, dysnatremia was recorded with the highest rate of electrolyte disturbances $(40 \%)$, especially hyponatremia (33.3\%), followed by dyskalemia (33.3\%), dysmagnesemia (24.4\%), and dyscalcemia (22.2\%). Electrolyte imbalance has severe effect on brain functioning. This may lead to severe complications like organ failures and ultimately can lead to death, [25]. This correlates well with the study Mieke et al., 2014, [15], which found that mortality rate of stroke patients with electrolyte imbalance was higher $(7.1 \%)$ than in patients with normal level. This is especially true for hypernatremia because of its contribution on the development of brain edema. Regarding potassium level dyskalemia was another predictor of short-term outcome of stroke cases, where dyskalemia was the second most commonly recorded (33.3\%) electrolyte disturbances among cases died within 1 st week of CVS. Among surviving cases, it was found that patients with hypokalemia, not amenable for correction, showed significant clinical deterioration with significant increase in NIHSS on discharge compared to that on admission along 1 st week of stroke. Similarly Salah and his colleagues 1997 reported that post stroke hpokalemia is common and associated with poor outcome (hazard ratio 1.73 (95\% CI: 1.03-2.9) for $1 \mathrm{mmol} / \mathrm{L}$ lower plasma $\mathrm{K}$ concentration), [26]. Hypokalemia in stroke patients, especially those with aneurysmal subarachnoid hemorrhage (aSAH), might be attributed to autonomic neural stimulation or elevated levels of catecholamine, as a result of stimulation of a (32-adrenergic receptors linked to $\mathrm{Na}+\mathrm{K}+$ adenosine triphosphatase (Na+/K+ ATPase), [27] In this present study we found that among cases who died, dyscalcemia was found in $22.2 \%$. Furthermore it was found that patients with dyscalcemia showed deterioration in terms of significant increase in NIHSS on discharge compared to that on admission even when Ca level was corrected. Interestingly, Appel et al., [28] reported that serum calcium levels at both extremes of range are associated with greater mortality.

However, Jong-Won Chung [29], found that albumin-corrected calcium levels has more prognostic significance than serum calcium in terms of early neurologic outcome and long-term mortality after acute ischemic stroke. Regarding Dysmagnesemia hypomagnesemia was recorded among $24 \%$ of patients died within the 1 st week of stroke. Among survival cases, patients with hypomagnesemia, especially those who were not amenable for correction, showed significant clinical deterioration. In accordance to the current results, cojocaru et al., [30], found that decrease in serum magnesium indicates severity of the stroke and a magnesium substituation may be useful. Similarly, Van den Bergh et al., [31] reported that hypomagnesemia is frequently seen between the 2 nd and 12 th day after SAH and is related to the severity of hemorrhage.

\section{In Conclusion:}

Electrolyte disturbance is a quite common problem that is encountered with acute CVS, particularly brain stem stroke. The problem necessitate rapid detection and careful monitoring as it closely affects short term prognosis and stroke outcome. 
Financial support and sponsorship: Nil.

\section{References}

1- DONNAN G.A., FISHER M., MACLEOD M. and DAVIS S.M. (May). "Stroke". Lancet, 371 (9624): 1612-23, 2008.

2- EL-TALLAWY H.N., FARGHALY W.M., BADRY R., HAMDY N.A., SHEHATA G.A., RAGEH T.A., METWALLY N.A., HASSAN E.M., ELSAYED S.S., YEHIA M.A. and SOLIMAN W.T.: Epidemiology and clinical presentation of stroke in Upper Egypt (desert area)". Neuropsyachiatric disease and treatment Dove press journal 21 August 2015. Neuropsychiatr Dis. Treat., Aug. 21; 11: 2177-83, 2015.

3- ROBERTSON G.L.: Disorders of the neurohypophysis. Harrison's principles of internal medicine. 17 th Ed. New York: McGraw Hill; p. 2217-23, 2008.

4- KRAUT A.J., ADROGUE H.J. and MADIAS N.E.: Respiratory and Mixed Acid Basedisorders in Brady HR, Wilcox CS (eds) Therapy in Nephrology andHypertension: A Companion to Brenner and Rectors The Kidney (WBSaunder's Company Philadelphia, 292-301, 1999.

5- SINGER G.G. and BRENNER B.M.: Fluid and electrolyte disturbances. Harrisons principles of internal medicine. 17th ed. New York: McGraw Hill, p. 274-85, 2008.

6- LIAMIS G., RODENBURG E.M., HOFMAN A., ZIETSE R., STRICKER B.H. and HOORN E.J.: Electrolyte disorders in community subjects: Prevalence and risk factors. Am. J. Med., 126 (3): 256-63, 2013.

7- CHUNG J.W., RYU W.S., KIM B.J. and Byung-Woo University, Seoul, Korea Yoond Elevated Calcium after Acute Ischemic Stroke: Association with a Poor ShortTerm Outcome and Long-Term Mortality, Article, Journal of Stroke, 17 (1): 54-9, 2015.

8- PHAM P.C., PHAM P.M., PHAM S.V., MILLER J.M. and PHAM P.T.: Hypomagnesemia in patients with type 2 diabetes. Clin. J. Am. Soc. Nephrol., 2: 366-73, 2007.

9- SAVER J.L., KIDWELL C. and ECKSTEIN M.: FASTMAG Trial Investigators. Prehospital neuroprotective therapy for acute stroke: Results of the field administration of stroke therapy magnesium (FAST-MAG) pilot trial. Stroke, 35: e106-8, 2004.

10- HASAN M.K., HASAN A.B. and RUBAIYAT K.A.: "Electrolyte Disturbances in Acute Phase of Stroke Patients". Dinajpur. Med. Col. J., Jan., 6 (1): 12-6, 2013.

11- SENELICK R.C., ROSSI P.W. and DOUGHERTY K.: Living with Stroke: A Guide for Families. Contemporary Books, Chicago, 1994.

12- National Institute of Neurological Disorders and Stroke (NINDS): "Stroke: Hope Through Research". National Institutes of Health, 1999.

13- Global Burden of Disease Study 2013, Collaborators (22 August 2015). "Global, regional, and national incidence, prevalence, and years lived with disability for 301 acute and chronic diseases and injuries in 188 countries, 19902013: A systematic analysis for the Global Burden of Disease Study. Lancet (London, England). 386 (9995): 743-800, 2013.

14- ALAM M.N., UDDIN M.J., RAHMAN K.M., AHMED S., AKHTER M., NAHAR N., SWAPAN M.K., ALAM
M.M., SULTANA N., HALLAZ M.M., ALAM M.M., UDDIN M.M., BARI M.S. and ISRAIL M.A.: Electrolyte changes in stroke Mymensingh. Med. J. Mymensingh. Med. J., Oct., 21 (4): 594-9, 2012.

15- MIEKE A.H.N. KEMBUAN1 and SEKPLIN A.S SEKEON2: Electrolyte disturbances among acute stroke patients in Manado, Indonesia, Global Journal of Medicine And Public Health, 2014.gjmedph.org Vol. 3, No. 1, 2014.

16- AUDIBERT G., STEINMANN G., De TALANCÉ N., et al.: Endocrine response after severe subarachnoid hemorrhage related to sodium and blood volume regulation. Anesth. Analg., 108 (6): 1922-8, 2009.

17- DIAZ J.L., GRANADOS M. and SUAREZ J.I.: Management of medical complications in the neuroscience critical care unit. In: Suarez JI. Critical care neurology and neurosurgery. New Jersey: Humana Press Inc., 2004.

18- KUSUDA K., SAKU Y., SADOSHIMA S., KOZO I., FUJISHIMA $M$. and NIHON RONEN IGAKKAI ZASSHI: Disturbances of fluid and electrolyte balance in patients with acute stroke, Jpn. J. Geriatr., May, 26 (3): 223-7, Japanese, 1989.

19- GUO Z., WANG T., ZHANG J.H. and QIN X.: Clinica analysis of electrolyte imbalance in thalamic hemorrhage patients within 24h after admission. Acta Neurochir. Suppl., 111: 343-8, 2011.

20- LATH R.: Hyponatremia in neurological diseases in ICU. Indian J. Critical Care Med., 9 (1): 47-50, 2005.

21- AIYAGARI V., DEIBERT E. and DIRINGER M.N.: Hypernatremia in the Neurologic Intensive Care Unit: How high is too high? Journal of Critical Care, 21: 163$72,2006$.

22- SIDDIQUI M.R., ISLAM Q.T., HAQUE M.A., IQBAL M.J., HOSSAIN A., RAHMAN Y.U., et al.: Electrolyte status in different type of acute stroke patients andtheir correlation with some common clinical presentation. J. Medicine, 13: 133-7, 2012.

23- HUANG W.Y., WENG W.C., PENG T.I., CHIEN Y.Y., WU C.L., LEE M., et al.: Association of hyponatremia in acute stroke stage with three-year mortality in patients with first-ever ischemic stroke. Cerebrovasc. Dis., 34: 55-62, 2012.

24- RODRIGUES B., STAFF I., FORTUNATO G. and LOUISE D. McCULLOUGH: Hyponatremia in the prognosis of acute ischemic stroke, Article in the press, 2013.

25- NEMADE S.T., PATIL M.S., CHAUDHARI R.A. and VANKUDRE A.J.: Serum Electrolyte Levels (Sodium and Potassium) in Cerebrovascular Accidents at a Tertiary Care Hospital-A Case Control Study, MVP Journal of Medical Sciences, Vol. 2 (1), 1-3, January-June, 2015.

26- SALAH E. GARIBALLA MRCP1, THOMPSON G. ROBINSON MRCP2 and Dr. MARTIN D. FOTHERBY MD2,*: Hypokalemia and Potassium Excretion in Stroke Patients, The American Geriatrics Society, 1997.

27- KIMURA Y., YAMAUCHI M., YAMAKAGE M., SUMITA S., KIMURA S. and Asahikawa Red Cross Hospital, Asahikawa, Japan: Hypokalemia in Patients With Aneurysmal Subarachnoid Hemorrhage is Accompanied by Elevated Serum Sodium Level, Journal of American Society of Anesthesiologists, 2012. 
28- APPEL S.A.1, MOLSHATZKI N., SCHWAMMENTHAL Y., MERZELIAK O., TOASHI M., SELA B.A. and TANNE: Serum calcium levels and long-term mortality in patients with acute stroke, Cerebrovasc. Dis., 31 (1): 93-9, 2011.

29- CHUNG J.W., RYU W.S., KIM B.J. AND Byung-Woo University, Seoul, Korea Yoond: Elevated Calcium after Acute Ischemic Stroke: Association with a Poor ShortTerm Outcome and Long-Term Mortality, Article, Journal of Stroke, 17 (1): 54-9, 2015.
30- COJOCARU I.M., COJOCARU M., BURCIN C. and ATANASIU N.A.: Serum magnesium in patients with acute ischemic stroke. Rom. J. Intern. Med., 45 (3): 26973, 2007.

31- VAN DEN BERGH W.M., ALGRA A., VAN DER SPRENKEL J.W., TULLEKEN C.A. and RINKEL G.J.: Hypomagnesemia after aneurysmal subarachnoid hemorrhage. Neurosurgery, Feb., 52 (2): 276-81; discussion 281-2, 2003. 


\section{إضطرابات نسبة الآملاح فى الجسم فى مرضى السكتة الدماغية}

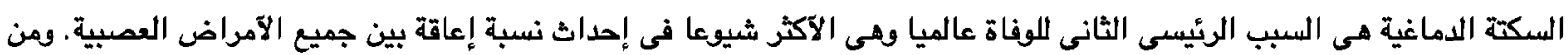

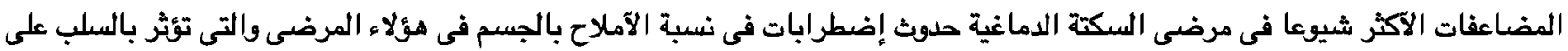
حالة المريض.

$$
\text { تهدف هذه الدراسة: }
$$

1- تقدير نسبة إضطرابات الآملاح بالجسم في مرضى السكتة الدماغية الحادة. r- تقييم العلاقة الحتملة بين إضطرابات الآملاح وشدة السكتة الدماغية وبين متابعة حالة المريض على المدى القصير.

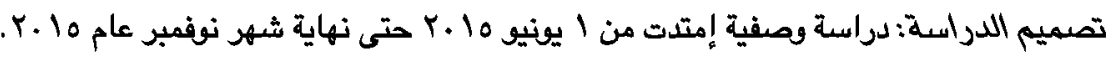

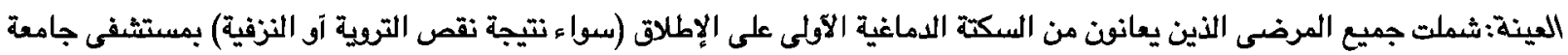

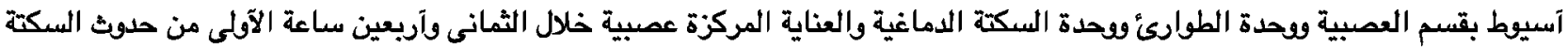

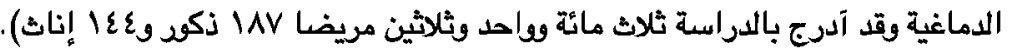
خضع جميع المرضى لما يلى: ا - تقييم حالة المريض من خلال آخذ التاريخ المرضى ويتم السؤال على تاريخ الإعتلال المشترك. ب- يتم السؤال على وعن تسجيل علاجات ما قبل السكتة الدماغية.

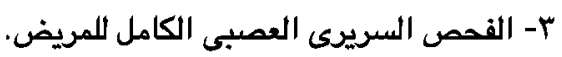
ع - تقييم شدة السكتة الدماغية عن طريق (NIHSS) عند الدخول ويوم بعد يوم حتى اليوم السابع آو الخروج. ه - تسجيل كيمياء الدم وتشمل (الصوديوم، البوتاسيوم، الكالسيوم المتآين والمغنسيوم المتآين) يوم بعد يوم حتى السابع آو الخرج. ج- تم تقييم نتائج قصيرة الآجل التى عن طريق حساب نسبة الوفيات خلال التقاجد بالمستشفى فى الإسبوع الآول ومن خلال تطود الصالة العصبية عند الناجين.

وقد تلخصت نتائج هذا العمل في الآتى:

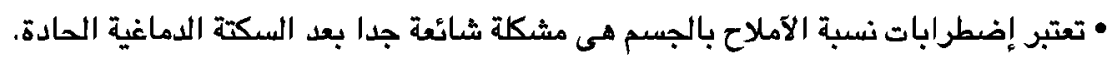

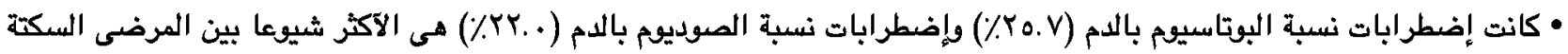
الدماغية.

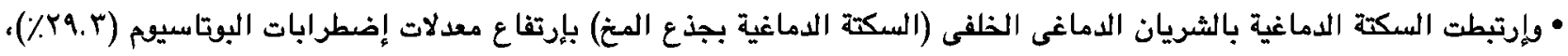

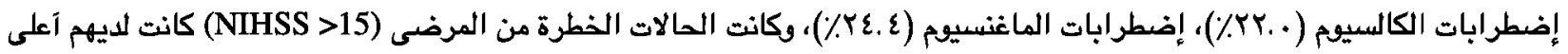
معدلات من إضطرابات نسبة الآملاح وكيمياء الدم. الفيات الماترات

• وكان مرضى السكرى على الآنسولين لديهم آعلى معدلات إضطرابات نسبة الآملاح، من تلك التى على مخفضات سكر الدم عن طريق الفم

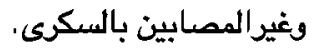

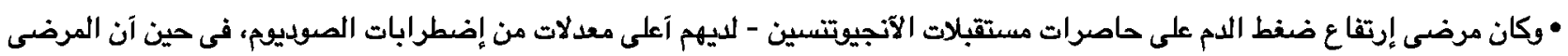

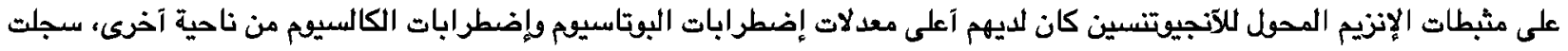

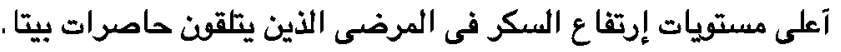

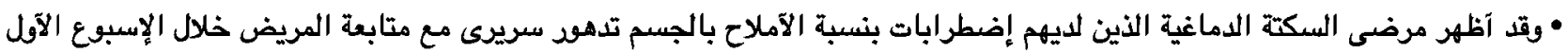

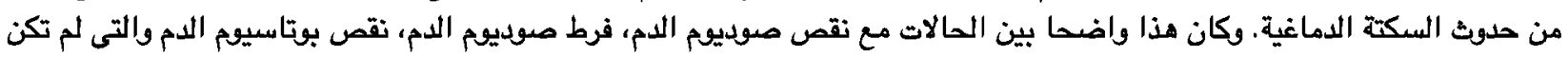
قابلة للتصحيح. • كانت إضطرابات الصوديوم ( ...ع) هى الآكثر شيوعا بين حالات الوفاة. 